UDC 621.391

\title{
MODERN APPROACHES TO TEACHING TELECOMMUNICATIONS DISCIPLINES
}

\author{
Serhii O. Kravchuk \\ Institute of Telecommunication Systems \\ Igor Sikorsky Kyiv Polytechnic Institute, Kyiv, Ukraine
}

Background. The directions and methods of training telecommunications personnel are constantly evolving in accordance with the growing volume of information exchange in society. Telecommunications as a display of the means and methods of information transmission have come a long way from purely radio engineering systems to heterogeneous systems with a complex network infrastructure and intelligent methods of information processing. Accordingly, the approaches to the training of telecommunications personnel are also changing. If in the early 80 s preference in training was given to radio technologies, now it is network and software technologies.

Objective. The purpose of this work is to present the possibilities of increasing the efficiency of the educational process in standard and mixed modes, structuring subjects in accordance with the requirements of the modern labor market.

Methods. The unpredictable deep essence and uncertainty of the information space of the professions for which higher education prepares students today leads to a change in the teaching paradigm. Methods and structuring of building the learning process with obtaining the maximum effect of the student's readiness for their practical activities are investigated.

Results. Possible ways of implementation of new requirements for personnel training for the new paradigm of the unified industry "Information Technologies and Telecom" are presented; the main directions of the formation of the general structure of training of telecommunications personnel on the example of the educational program "Engineering and programming of infocommunications"; recommendations for the organization of the educational process in full-time and remote modes. It is shown that with the correct organization of the educational process, blended learning can improve the quality of learning, especially in the context of reducing the hours of "classroom lessons" by transferring part of the educational process to the online environment.

Conclusions. University graduates constitute the potential foundation of today's specialist market. Nevertheless, the problem of their professional adaptation, at the moment, remains relevant. Therefore, the paper proposes to solve this problem using the presented multilateral approach.

Keywords: telecommunications; electronic communications; infocommunications; training; information technology; telecom.

\section{INTRODUCTION}

The directions, methods and structures of training telecommunications personnel are constantly evolving in accordance with the needs of society and the growing volume of information flow in society. All the time, there is a change in the paradigms of the information exchange infrastructure and the use of new technologies for the transfer and accumulation of information.

Telecommunications as a reflection of the means and methods of information transmission have come a long way from purely radio engineering systems, where radio technologies for signal generation and transmission predominated, to heterogeneous systems with a complex self-organizing network infrastructure and intelligent methods of processing the transmitted information [1-7]. Accordingly, the approaches to the training of telecommunications personnel are also changing. If in the early 80 s preference in training was given to radio technologies, now it is network and software technologies. Hence, the main emphasis in the training of specialists is infocommunication systems and technologies.

The dynamic development of infocommunication technologies requires a new level of personnel capable of quickly adapting to the business environment. It is necessary to increase the mobility of the vocational training system, taking into account the needs of the labor market.

Both employers and teachers understand that labor markets and educational services need harmonization in terms of the number and quality of training.

It is the business factor that comes to the fore in gaining solid knowledge. Professional training of students - ideally - should harmonize the educational process, scientific achievements in telecommunication technologies and market needs as much as possible. Of course, the content and quality of higher education depends on the level of implementation of information and communication technologies. Ukrainian business 
structures have realized the need to improve education. But employers in this area are not yet ready to take responsibility for participating in the process of training specialists.

As evidenced by the personnel policy of many domestic companies, entry-level vacancies are often provided to graduates. And mainly with the possibility of professional and career growth.

In particular, among the problems are the abolition of obsolete professions, the lack of a systematic approach to the nomenclature of professions, and there are no qualifications for a significant number of professions. The job responsibilities of workers in new professions should also be defined.

\section{MODERN TRENDS IN THE MARKET OF YOUNG PROFESSIONALS IN THE FIELD OF TELECOMMUNICATIONS AND INFORMATION TECHNOLOGIES}

The relevance of the problem of understanding the modern needs of the market of young specialists in the field of "Telecommunications and Information Technologies" is justified by the fact that senior students, after receiving the appropriate education or even during training, constitute the potential basis of the modern market of specialists. However, the problem of their professional adaptation, at the moment, is not sufficiently studied by the universities themselves.

Any information or knowledge tends to become obsolete, for example, according to the results of independent research conducted in 2008 [8], the knowledge of graduates at the time of graduation from the university lagged behind real trends by 5-6 years. Over the past few years, this indicator has decreased to 1-2 years, due to the fact that virtually any information has become easily accessible through the Internet, some of the students began to monitor market trends and devote time to self-education. In their senior years or graduating from university, students begin their first steps in looking for a job and come to the idea that they will now have to move from theory to real practice. The first test they will have to overcome on the way to the desired job is that the theory they studied can be very different from real practice, and in some cases, even the theory itself may be outdated and not consistent with the latest trends. Many of them will begin to lose confidence in their knowledge and powers, motivation will begin to fade away, and some completely ask themselves and begin to go with the flow, never trying their hand at the desired specialization and perhaps not revealing their real potential. There is a great need to fill knowledge gaps, taking into account current trends in a specific direction.

Absolutely all applicant companies want to get a specialist from the start who will immediately start performing his work duties by $50-70 \%$, begin to solve real project tasks, and will not require more investment in introducing the project into the course and adapting to modern (real) approaches and concepts that are inherited by all modern companies in the field of Telecommunications and Information Technologies. These measures will help overcome negative stereotypical opinions of employers about hiring graduate students.

Currently, employers have very high requirements for the qualifications and length of service of specialists, including this requirement for university graduates [912]. But it is quite obvious that young specialists will not have sufficient practical experience, which is required of them when they are hired, as a result, a "vicious circle" is created when a student with higher professional education in the required specialization cannot be interviewed for the relevant position in mind lack of the required practical experience and is forced to look for work in another field of activity that does not correspond to their education. Today's competition in the labor market has led to the fact that young specialists do not have clear information about the demand and rating of their profession on the market, do not have information about the real requirements for the positions they are applying for.

Today one often hears the opinion that there are more young specialists on the market than necessary. They talk about this in relation to some cities, such as Kyiv, Odesa, Lviv, Kharkiv.

Educational institutions that train relevant specialists are not keeping pace with the rapid development of the market, both quantitatively and qualitatively. The rate of obsolescence of information today is such that the knowledge acquired by students in the learning process most often becomes irrelevant already upon receiving a diploma. University graduates in most cases do not have the skills that are in demand at this time.

There is a shortage of specialists in various segments: development of information systems, implementation, support, information security.

This situation has arisen due to the intensive development of the IT market. Education does not keep pace with this growth. We have many higher educational institutions, but few teach technologies and products that are now in demand and are actively used by key employers. The problem is that such training requires the development of appropriate curricula, the availability of trained teachers, and a material base is 
also needed, that is, the appropriate software and hardware with the help of which students could in practice master the acquired knowledge. All this requires serious investment. Not all universities can afford it.

Today, large companies, such as "Infopulse", are developing training programs in order to implement them in various training centers. This approach slightly reduces the shortage of qualified specialists, but only on the scale of one or several companies.

The main problem of universities today is that they cannot keep up with the pace of technology development, the release of new products, programming languages, protocols, new approaches in computer engineering.

Universities, as before, provide basic knowledge, expanding the horizons of students. But they do not give actual knowledge of certain areas or practical skills. Training centers established at universities by large companies can and significantly improve this situation, but at the moment such undertakings are rather poorly developed in Ukraine. The chances of successful employment among students who have also completed additional training in specialized training centers are much higher than: often employers themselves request specialists there.

Also, over the past five years, the level of wages in our country has significantly increased, which in turn has significantly reduced the outflow of specialists abroad. Due to the gradual leveling of conditions, highly qualified specialists circulate. Many go abroad for a while and return with new experiences and career opportunities. A large number of good specialists have appeared who, in principle, do not want to work abroad. The difference in wages abroad and in our country has significantly decreased.

There is the following dependence - a specialist will work for a long time and work well only if he suits the company, and the company suits him.

How can the situation be improved after all? First, it is possible to organize targeted training of university graduates. This will make it possible not only to select the necessary young specialists but also to reduce the costs of companies associated with the adaptation or retraining of university graduates. Conduct constant monitoring of market trends, technologies, modern approaches. Based on this information - adaptation, additions to educational programs.

Attracting individual companies or practicing experts to cooperate in the process of modernizing curricula, teaching.

A separate step in these approaches deserves the "Interest" and "Motivation" of the students themselves to acquire knowledge, as well as the opportunity to learn from the real experience of qualified experts at the training stage.

The main goals that should be pursued are:

- to acquaint students with the latest trends in the development of world leaders in the field of hardware and software information technologies, processes, and approaches, to develop their practical skills based on theoretical knowledge, to give more real examples of existing practices.

- to offer the opportunity, in addition to the diploma, to receive certificates that, in their future career aspirations, will correspond to their preferences and which will confirm practical skills in the chosen field. This will significantly increase their competitiveness in the market.

These approaches will make it possible to train competent practitioners, reduce the so-called "brain drain", increase the level of motivation and interest of students in acquiring knowledge, modernize the educational process in accordance with modern market requirements, increase the percentage of student employment in the desired specialization, and dispel negative employers' stereotypical attitudes about hiring graduate students.

\section{BASIC TRAINING CONCEPTUAL MODEL}

Considering the above, the structure of personnel training at the Department of Telecommunications of the Igor Sikorsky Kyiv Polytechnic Institute for the educational program "Engineering and Programming of Infocommunications", which is based on six basic principles of ensuring high quality of training of students, is close to the presented message:

- reliance on scientific research;

- a combination of experienced and young teachers in the selection of cadres;

- development of its own methodological support, publication of monographs, textbooks, and software packages;

- interaction with partners from other countries;

- close cooperation with telecommunications and IT companies;

- attraction of specialists from leading IT and Telecom companies to teach;

- creation, support, and upholding of the image (prestige) among students as a leading technical educational institution with age-old traditions of the formation of experienced engineering and scientific personnel;

- taking into account the needs of modern business;

- combined online / off-line training;

- integration with the best world practices. 
Engineering and programming of infocommunications is based on a combination of knowledge and skills in programming and functioning of devices, systems, and networks in the field of Information Technology (IT) and information transfer technologies (Telecommunications), aimed at processing and transferring any information.

The educational program is defined by three words infocommunications, engineering, and programming. Here, Infocommunications is a set of IT and Telecom, which in the process of processing and transferring information act as a single whole. Engineering is the creation of Hard hardware for electronic communications systems; configuration, administration, and organization of computer networks and the Internet, mobile communication systems, virtual reality systems. Moreover, training on equipment is carried out on a unique laboratory base provided by leading IT and Telecom companies, as well as used for complex scientific research.

Programming has three combined components:

1) fundamental basic training - software engineering and testing, programming languages $(\mathrm{C} / \mathrm{C}++$, Java, Python, etc.), algorithms, databases, web programming, functional and object-oriented programming;

2) in-depth training: business analysis, Big Data, cloud technologies, cybersecurity, multi-threaded processes;

3) unique training: counteracting hacker attacks, programming applications of computer specialized networks and mobile devices, creating so-called embedded systems, which are devices or systems whose operation is completely determined by software - their great need is not only in communications but also in robotics, artificial intelligence.

Strengthening the IT component in the training of specialists in the field of telecommunications can be explained as follows.

Recently, when creating a telecommunications system (TCS), more and more attention is paid to the universality of the solutions used, to increase their degree of integration and functional content, which resulted in the emergence of the concept of SDR (Software Defined Radio). The SDR concept envisages replacing the entire variety of existing and developing designs of transceiver equipment with a limited number of available hardware blocks running under software control. This leads to a simplification and cost reduction of the final product, a significant improvement in characteristics, support for any types of modulation, anti-jamming coding, the implementation of complex digital processing algorithms, and the emergence of a large number of additional service functions ... The development of the final product is significantly accelerated since the software can be improved simultaneously by different groups of developers within the framework of a single hardware and software platform.

In addition, the development of specialized software for creating reconfigured TCS protocols has become widespread. At the same time, solutions are acquired for the creation of next-generation telecommunication networks and distributed networks with selforganization.

Thus, the creation and functioning of modern telecommunications increasingly rely on specialized software that allows you to combine modern computer facilities with nodes and subsystems of the TCS while increasing their productivity and providing the ability to create multifunctional, multistandard, and open telecommunication multiservice platforms.

The curriculum of the educational program combines 8 training cycles (Fig. 1):

- basic university-wide humanitarian and socioeconomic;

- basic natural science;

- basic professional;

- information technologies;

- network technologies;

- cybersecurity in infocommunications;

- modern infocommunication systems;

- mobile infocommunication systems.

The first basic cycle is distributed over all semesters and is intended for training in the economic and humanitarian sense. Unfortunately, the first cycle is appointed by the university without the possibility of adjustment by the graduating department. This cycle includes "History of Science and Technology", "Introduction to Philosophy", "Fundamentals of a Healthy Lifestyle", "Environmental Protection Strategy", "Economics and Organization of Production", "Business Law" and others.

The second basic cycle includes basic general education subjects necessary for the initial training of an engineer. This is, first of all, the classical "Higher Mathematics" and "Special Mathematics" (theory of probability and mathematical statistics, the basics of mathematical modeling), "General Physics", which considers two sections: electricity and magnetism and wave processes (optics and quantum mechanics)), "Engineering and Computer Graphics", a discipline of an almost professional direction "Fundamentals of Metrology", the discipline "Informatics", which is a basic discipline that directs students to use information 

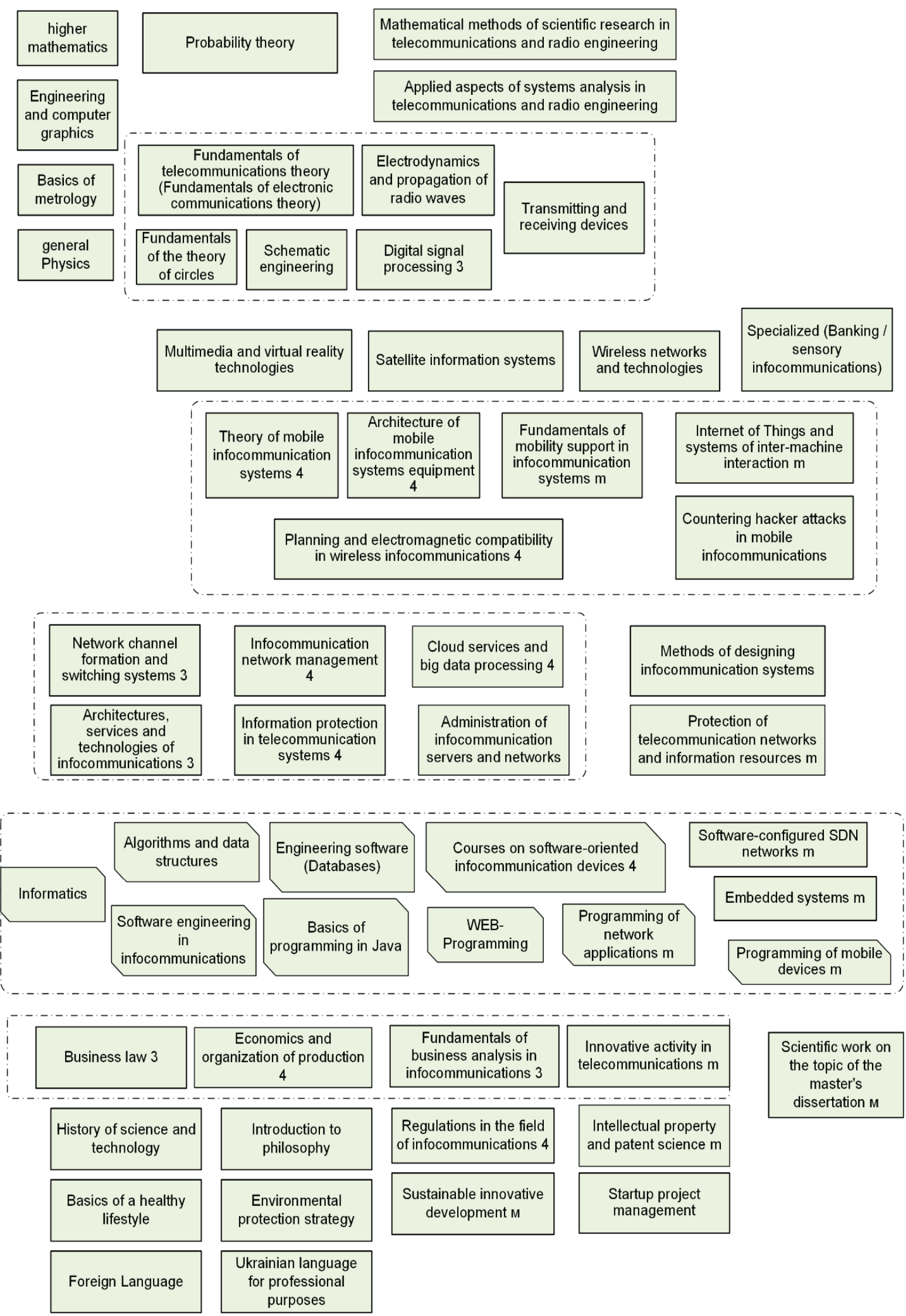

Fig. 1. The structure of subjects and cycles of training specialists in the telecommunications profile of the Department of Telecommunications I. Sikorsky KPI (m - magistracy) 
technology in subsequent professional disciplines (computer technology, programming technologies), algorithmic programming, the basics of object and system programming).

The following cycles form the backbone of the main professional training of a specialist. Let's dwell on them in more detail.

The basic professional cycle consists of the classical disciplines: "Fundamentals of the theory of telecommunications" (information theory, communication channels, multichannel systems, modulation and demodulation, characteristics of signals and communication systems, optimal receivers, carrier and clock synchronization, channel bandwidth and coding, communication systems many users), "Fundamentals of circuit theory", "Electrodynamics and propagation of radio waves", "Circuitry" (digital circuitry, microelectronics, microprocessors), "Digital signal processing" (fundamentals of signal analysis, discrete systems, spectral analysis, discrete filters), "Transmitting and Receiving Devices". This cycle is inherent in all educational programs in the direction of radio engineering and telecommunications.

It should be noted that the end-to-end continuous training of students in information technology, incorporated in the educational process of the department. The flow of information disciplines, started by "Informatics" in the second cycle of training, is consistently developing and supplementing narrowly specialized disciplines with software tools. This stream consists of the following disciplines: "Algorithms and data structures", "Software engineering in infocommunications", "Engineering software. Databases", "Fundamentals of Java programming", "WEB programming", "Programming network applications", "Educational disciplines on softwareoriented infocommunication devices","Softwareconfigured networks SDN", "Embedded systems", "Programming mobile "devices", "Fundamentals of business analysis in infocommunications".

The next training cycle is network technologies: "Architectures, services and technologies of infocommunication", "Systems of network channeleducation and switching", "Management of infocommunication networks", "Cloud services and processing of big data", "Administration of infocommunication servers and networks "," Methods for designing infocommunication systems.

The formation of a cycle on cybersecurity in infocommunications is provided by the following disciplines: "Protection of information in telecommunication systems", "Protection of telecommunication networks and information resources", "Counteraction to hacker attacks in mobile infocommunications".

Cycle of modern infocommunication systems: "Satellite information systems", "Technologies of multimedia and virtual reality", "Wireless networks and technologies", "Specialized (Banking / Sensory) infocommunications", "Internet of things and systems of machine-to-machine interaction ".

The cycle on mobile infocommunications (cellular mobile communication systems), which are currently undoubtedly the leaders in the telecommunications field, is highlighted separately. This cycle includes "Theory of mobile infocommunication systems", "Equipment architecture of mobile infocommunication systems", "Planning and electromagnetic compatibility in wireless infocommunications", "Fundamentals of mobility support in infocommunication systems". As part of the cycle of mobile infocommunications, three scientific and educational laboratories have been deployed.

Special attention to the cycle of mobile infocommunications is due to their dominant position in the field of telecommunications. Yes, the main trend in the development of modern telecommunications is to provide high-quality communications for the exchange of information for any users or intelligent machine objects, regardless of their location and speed. At the same time, users should have complete independence and freedom of movement, that is, mobility. The convergence of technologies, systems, and services allows extending support for mobility to the entire telecommunications infrastructure and reaching a new modern level of their development - mobile infocommunications [13].

The central place in the cycle is occupied by mastering methods of supporting mobility in modern cellular systems, including the 5th and 6th generations, broadband access systems, heterogeneous multi-level distributed telecommunication networks based on various technologies and architectures.

\section{ON CONDUCTING LECTURES REMOTELY}

The topic of increasing the efficiency of conducting classes (educational process) with students is always relevant for the research and teaching staff of any higher educational institution $[14,15]$. This is all the more relevant when it is necessary to conduct the educational process in unusual (non-traditional) conditions of an unfavorable epidemiological situation associated with the spread of coronavirus disease (COVID-19) and the requirements for compliance with anti-epidemic measures, as well as in other situations that provide for the inability to produce the educational 
process in the traditional mode In such conditions, the organization of the educational process in a distance mode is at the forefront.

In this work, the authors, on the basis of the experience gained during the year when teaching a number of disciplines, to students of the Department of Telecommunications in a remote mode, are invited to answer two important methodological questions. What is the difference between the procedure for conducting a lecture remotely from the usual traditional lecture in the classroom? Is there a need to modify the traditional remote lecture procedure to make it more effective?

Currently, the organization of the educational process in a distance mode in the I. Sikorsky KPI is carried out in accordance with the "Regulations for the organization of the educational process in a distance mode". According to the Regulations clause 2.6. - A lecture in remote mode provides that applicants will receive information on the lecture material through telecommunications in a synchronous mode - when applicants receive information from the lecturer, with the ability to ask him questions in real time, or in the form of a problem discussion, processing additional material or such, requiring clarifications (organizing video conferencing), or in asynchronous mode - when applicants receive an audiovisual recording of lecture material in the form of web pages or in another format suitable for use on the Internet. The lecture material must be posted on the Sikorsky Platform or on another resource and be available to applicants.

Lecture platforms: traditional - auditorium, means of displaying information (board, projector, etc.), lecturer and listeners; remote - means of access to the Internet, software applications are able to support video conferences for many participants, lecture material in electronic form, virtual images of students and lecturers.

The peculiarities of conducting lectures for the specialty of a telecommunications profile are the complexity of the submitted material, the large volume and variety of material, the combination of the study of software, equipment and network structures and protocols.

In general, a lecture is the main form of conducting training sessions designed to assimilate theoretical material. Lecture is the main form of the educational process in higher education. Oral presentation of the subject by the teacher, as well as public reading on any topic. Traditional lectures are held in equipped rooms auditoriums for one or more academic groups of students. Carrying out lectures in small, medium-sized academic groups allows for special lectures-discussions or lectures-conversations (dialogue with the audience).
The main advantages of traditional education: direct personal communication with the teacher, as well as communication with other students; the ability to assess the readiness of the audience for the perception of the material by the lecturer and its adaptation to the audience; concentration of students and the teacher at the lecture; the existing methodology of the lecturer for teaching in the classroom, worked out over the years.

According to Wikipedia, certain typical shortcomings of traditional lectures should be named:

- the information provided by the teacher is aimed mainly at the student's auditory memory. This type of memory is rather imperfect. Research shows that by the end of a lecture, a student can reproduce only $10-15 \%$ of the entire volume of information presented;

- large streams of listeners (more than 50) deprive the teacher of the opportunity to effectively manage the mental activity of students;

- junior students have little command of the methodology and technique of perceiving the content of the lecture and taking notes;

- the lecture, to a certain extent, teaches the student to passive appropriation of other people's opinions, does not stimulate the desire for independent learning, does not provide an individual, differentiated approach to learning.

The convenience and advantages of distance learning over other forms of education are as follows. The main advantage of distance learning over full-time education is, first of all:

- the ability to study at any time. A student studying remotely can independently decide when and how much time during the semester to devote to the study of the material. He builds himself an individual training schedule;

mobility. Communication with teachers, tutors is carried out in different ways: both on-line and offline;

- the opportunity to learn at your own pace. You can always return to the study of more complex issues, watch video lectures several times, re-read the correspondence with the teacher, and already known topics can be skipped;

- the ability to study anywhere. Students can study from the comfort of their home or office, from anywhere in the world;

- learning in a relaxed environment. Intermediate certification of students of distance courses takes place in the form of on-line tests. Therefore, students have less reason to worry before meeting teachers for tests and exams; 
- replacement of abstracts with electronic resources and the latest teaching methods, constant consultations with a teacher provide this form of education with additional advantages over full-time. Among the disadvantages should be highlighted:

- technical aspect - students may not always have the necessary technical equipment: a computer or Internet access;

- lack of direct personal communication with the teacher, as well as communication with other students;

- psychological and "computer" unpreparedness of teachers. This is due to the traditional teaching methodology, which presupposes not virtual, but direct communication between the student and the teacher;

- significant financial expenses for the university, because it is necessary to update the material base, computer equipment, allocate premises, provide teachers with Internet access, etc.

- in Ukraine there are still no clear technological possibilities for student authentication;

- for distance learning, you need to have strong motivation and self-organization, because distance learning is, first of all, self-education, that is, the student's ability to work independently.

In addition, research at Stanford University has found the psychological effects of long hours of daily use of Zoom and other popular video chatting platforms, leading to fatigue. It:

1) too much close intense eye contact (such an amount of eye contact and the size of faces on the screen, as in chat rooms, is unnatural for a person);

2) an unnaturally long contemplation of one's face (people become more critical of themselves when they see their reflection);

3) a sharp decrease in mobility (personal and telephone conversations allow people to walk and move) and during a video conference, the user has to stay in the same place;

4) an increase in cognitive load (in chats we have to try harder to send and receive messages - people have to control whether they have left the frame, whether gestures are noticeable enough, etc.).

During the transition from traditional to distance learning, a number of important factors can be lost: control over the audience, immediacy in communication, identification of listeners, preliminary assessment of the volume of mastering the material.

It is also necessary to take into account the general problem of lecture courses, since different generations of students have different assimilation of the material. That is, depending on the generation of students, the perception of information changes - the time of effective continuous perception. In this way, the streams of listeners can be divided into four classes of time of perception of the lecture material:

1) arriving at the beginning of 2000-2005. - from 10 min. up to $40 \mathrm{~min}$.;

2) incoming mid-2006-2010. - from 5 min. up to 25 $\min$;

3) incoming mid-2011-2018 - from $1 \mathrm{~min}$. up to 10 min.;

4) incoming 2019-2021 - from $30 \mathrm{~s}$ to $3 \mathrm{~min}$.

If not producing streaming large academic groups, then a form of training can be effectively used. Training and traditional forms of education have significant differences. Traditional training is mainly focused on the correct answer, while training is primarily focused on questions and search. Unlike traditional forms of training, training forms of education fully cover the entire potential of a person: the level and scope of his competence (social, emotional and mental), independence, ability to make decisions, interact, etc. Of course, the traditional form of knowledge transfer is not in itself something negative, but in the world of rapid changes and continuous obsolescence of knowledge, it has a narrowed scope of application.

In a training lesson, preference is given not to the activities of a teacher, but of students, whose personal experience is the basis of learning. It is not worth giving lectures, it will be advisable if the students share what they know at the moment, and they themselves find and / or assimilate the missing information.

Thus, in our opinion, in order to increase the efficiency of distance learning, it is necessary to carry out: a departure from the traditional conduct of lectures. Reducing the temporary continuous presentation of the material, maintaining the lecture-training form - for small and medium academic groups; for streaming (listeners more than 50...80) lectures, broadcasting prepared recorded video lectures with subsequent automatic testing of listeners; the most effective work of videoconferencing with medium and small academic groups; an increase in the number of ongoing tests; addressing the problem of identifying listeners is a necessary clear statement.

\section{Conclusion}

Approaches are proposed to improve the training of competent practitioners with an increase in the level of motivation and interest of students in acquiring knowledge, modernization of the educational process in accordance with modern market requirements.

The conceptual model of basic training of a specialist in IT and Telecom is presented on the example of the 
educational program "Engineering and programming of infocommunications". This educational program allows training specialists who will possess not only knowledge of the development, debugging, administration and improvement of the infocommunication infrastructure of operators / service providers (especially 5G mobile cellular systems), television, data transmission (Internet services), as well as knowledge infocommunication systems and technologies for the formation of a software platform, languages and programming tools, specialized software applications, protocols and technologies for processing and transferring data with a given quality of service, as well as virtual reality, "cloud" technologies, Internet of Things IoT (Internet of Things) and systems between machine interoperability M2M/D2D. What makes such graduates competitive in the IT and telecom market.

It is proposed that in order to increase the efficiency of distance learning, it is necessary to move away from the traditional lectures with a decrease in the temporary continuous supply of material, maintaining a lecturetraining form, broadcasting prepared video lectures, followed by automatic testing of listeners.

The issues raised in the article do not exhaust the entire problematic of increasing the effectiveness of training specialists in the telecommunications profile. Therefore, the subsequent work can be an in-depth study and analysis of the procedures for interaction of the graduate departments of the university with companies in the field of IT and telecom.

\section{REFERENCES}

1. M.Y. Ilchenko, S.O. Kravchuk, Telecommunication systems: Kyiv, Naukova dumka, 2017, 736 p. (ISBN: 978-966-00-1566-1), (in Ukraine).

2. I.M. Kravchuk, S.O. Kravchuk, "Approaches and innovations in teaching discipline of the telecommunication direction", Dig. of the Eleventh International Scientific conf. "Modern Challenges in Telecommunications", april 18-21, 2017, Kyiv, Ukraine. - pp. 191-192 (2017).

3. S.P. Morreale, J.C. Pearson, "Why Communication Education is Important: The Centrality of the Discipline in the 21st Century",
Communication Education, Vol. 57, No. 2, pp. 224-240 (2008) (DOI: 10.1080/03634520701861713).

4. 5G NR: The Next Generation Wireless Access Technology / edited by E. Dahlman, S. Parkvall, J. Skold, London: Academic Press, 2018, 468 p. (ISBN 978-0-12-814323-0).

5. S. Kravchuk, L. Afanassieva, "Development of telecommunication technologies as a factor of modern economic system", Materials of International scientific and practical conf. "Economics, science, education: integration and synergy", Bratislava, Slovak Republic, 18-21 January, 2016: in 3 vol. - Vol. 3. - pp. 97-98 (2016).

6. M.Y. Ilchenko, S.O. Kravchuk, "On Learning lectures in the remote mode", Proceedings of the International Scientific Conference " Modern Challenges in Telecommunications", 19-22. Retrieved from http://conferenc.its.kpi.ua/proc/article/view/229261 (2021: Proceedings of the fifteenth International Scientific and Technical Conference 12-16 April 2021, Kyiv, Ukraine). Platform \& workflow by OJS/PKP (2021).

7. S.O. Kravchuk, I.M. Kravchuk, V.S. Yavisya, "Formation of system structure for personnel training of telecommunication profile". in monograph: Advanced in the telecommunications 2019 / by edited M.Y. Ilchenko, S.O. Kravchuk, Kyiv, pp. 38-55 (2019).

8. I. Shevchenko, M. Chub, E. Rizcova, "Modern tendencies of the young specialist's market in the field of "Telecommunications and Information Technologies": directions "Business Analysis in Telecommunications" and "Software Quality Assessment", Proceedings of the International Scientific Conference " Modern Challenges in Telecommunications", 2017. Retrieved from http://conferenc.its.kpi.ua/proc/article/view/99661.

9. Modern Telecommunications. Basic Principles and Practices, By Martin J N Sibley, CRC Press, 202 p. (2018) ISBN 9781138578821

10. Information and communication technology (ICT) in education, Site belongs to UNESCO's International Institute for Educational Planning. Retrieved from https://learningportal.iiep.unesco.org/en/issuebriefs/improve-learning/information-and-communication-technology-ict-ineducation

11. M. Alawamleh, L. M. Al-Twait and G. R. Al-Saht, The effect of online learning on communication between instructors and students during Covid19 pandemic, Asian Education and Development Studies, August (2020) (DOI: 10.1108/AEDS-06-2020-0131). Retrieved from https://www.researchgate.net/publication/343897561

12. Innovative Approaches to Teaching Technical Communication, By $\mathrm{T}$. Bridgeford, K. S. Kitalong, R. Selfe, All USU Press Publications, 370 p. Retrieved from https://digitalcommons.usu.edu/usupress_pubs/147

13. M. Ilchenko, S. Kravchuk, Mobile infocommunication systems, Information and Telecommunication Sciences, Vol. 11, Number 1, pp. 11-19 (2020), (DOI: https://doi.org/10.20535/2411-2976.12020.11-19)

14. Advanced in the telecommunications 2019: monograph / by edited M.Y. Ilchenko, S.O. Kravchuk, Kyiv, 2019, 336 p. (ISBN 978-617-7734-12-2).

15. N.I. Machinskaya, S.S. Stelmakh, Modern forms of organizing the educational process in higher education: teaching aid, Lviv State University of Internal Affairs, 2012.- 180 p. ISBN 978-617-511-119-2.

\section{Кравчук С.O.}

\section{Сучасні підходи у викладанні дисциплін телекомунікаційного спрямування}

Проблема. Напрями та методи підготовки кадрів телекомунікаційного профілю постійно розвиваються відповідно до зростаючого обсягу обміну інформацією в суспільстві. Телекомунікації як відображення засобів та методів передачі інформації пройшли довгий шлях від суто радіотехнічних систем до гетерогенних систем зі складною мережною інфраструктурою та інтелектуальними методами обробки інформації. Відповідно, змінюються і підходи до підготовки кадрів телекомунікаційного профілю. Якщо на початку 80-х років. перевага в підготовці надавалася радіотехнологіям, то в даний час - мережним та програмним технологіям.

Мета Метою даної роботи є представлення можливостей підвищення ефективності проведення навчального процесу в стандартному та змішаному режимах, структуризації предметів відповідно до вимог сучасного ринку праці.

Методи. Непередбачувана глибинна сутність та невизначеність інформаційного простору професій, до яких готує студентів сьогодні вищу освіту, призводить до зміни парадигми навчання. Досліджуються методи та структуризація побудови процесу навчання з отриманням максимального ефекту готовності студента до своєї практичної діяльності.

Результати. Наведено можливі шляхи реалізації нових вимог до підготовки кадрів для нової парадигми єдиної галузі «Інформаційних технологій та Телекому»; основні напрями становлення загальної структури підготовки кадрів 
телекомунікаційного профілю 3 прикладу навчальної програми «Інженерія та програмування інфокомунікацій»; рекомендації організації навчального процесу в очному та дистанційному режимах. Показано, що за правильної організації навчального процесу змішане навчання здатне підвищити якість навчання, особливо, за умов скорочення годин «аудиторних занять» 3 допомогою переведення частини навчального процесу в онлайн середовище.

Висновки Випускники університетів становлять потенційну основу сучасного ринку спеціалістів. Проте, проблема їхньої професійної адаптації, на даний момент, залишається актуальною. Тож у роботі запропоновано вирішувати цю проблему з допомогою представленого багатостороннього підходу.

Ключові слова: телекомунікації; електронні комунікації; інфокомунікації; навчання; інформаційні технології; телеком.

\section{Кравчук C.A.}

Современные подходы в преподавании дисциплин телекоммуникационного направления

Проблематика. Направления и методы подготовки кадров телекоммуникационного профиля постоянно развиваются в соответствии с растущим объемом обмена информацией в обществе. Телекоммуникации как отображение средств и методов передачи информации прошли долгий путь от чисто радиотехнических систем до гетерогенных систем со сложной сетевой инфраструктурой и интеллектуальными методами обработки информации. Соответственно изменяются и подходы к подготовке кадров телекоммуникационного профиля. Если в начале 80-х гг. предпочтение в подготовке отдавалось радиотехнологиям, то в настоящее время - сетевым и программным технологиям.

Цель Целью данной работы является представление возможностей повышения эффективности проведения учебного процесса в стандартном и смешанном режимах, структуризации предметов в соответствии с требованиями современного рынка труда.

Методы. Непредсказуемая глубинная сущность и неопределенность информационного пространства профессий, к которым готовит студентов сегодня высшее образование, приводит к изменению парадигмы обучения. Исследуются методы и структуризация построения процесса обучения с получением максимального эффекта готовности студента к своей практической деятельности.

Результаты. Представлены возможные пути реализации новых требований к подготовке кадров для новой парадигмы единой отрасли «Информационных технологий и Телекома»; основные направления становления общей структуры подготовки кадров телекоммуникационного профиля на примере учебной программы «Инженерия и программирование инфокоммуникаций»; рекомендации организации учебного процесса в очном и дистанционном режимах. Показано, что при правильной организации учебного процесса смешанная учеба способна повысить качество учебы, особенно, в условиях сокращения часов «аудиторных занятий» за счет перевода части учебного процесса в онлайн среду.

Выводы Выпускники университетов составляют потенциальную основу современного рынка специалистов. Тем не менее, проблема их профессиональной адаптации, на текущий момент, остается актуальной. Поэтому в работе предложено решать данную проблему при помощи представленного многостороннего подхода.

Ключевые слова: телекоммуникации; электронные коммуникации; инфокоммуникации; обучение; информационные технологии; телеком. 